\title{
Hemotropic mycoplasmas in little brown bats (Myotis lucifugus)
}

\author{
Patricia E Mascarelli ${ }^{1}$, Michael K Keel ${ }^{2,3}$, Michael Yabsley ${ }^{2,4}$, Lisa A Last ${ }^{2}$, Edward B Breitschwerdt ${ }^{1}$ \\ and Ricardo G Maggi ${ }^{1 *}$
}

\begin{abstract}
Background: Hemotropic mycoplasmas are epicellular erythrocytic bacteria that can cause infectious anemia in some mammalian species. Worldwide, hemotropic mycoplasmas are emerging or re-emerging zoonotic pathogens potentially causing serious and significant health problems in wildlife. The objective of this study was to determine the molecular prevalence of hemotropic Mycoplasma species in little brown bats (Myotis lucifugus) with and without Pseudogymnoascus (Geomyces) destrucans, the causative agent of white nose syndrome (WNS) that causes significant mortality events in bats.
\end{abstract}

Methods: In order to establish the prevalence of hemotropic Mycoplasma species in a population of 68 little brown bats (Myotis lucifugus) with $(n=53)$ and without $(n=15)$ white-nose syndrome (WNS), PCR was performed targeting the 165 rRNA gene.

Results: The overall prevalence of hemotropic Mycoplasmas in bats was 47\%, with similar $(p=0.5725)$ prevalence between bats with WNS (49\%) and without WNS (40\%). 16S rDNA sequence analysis ( 1,200 bp) supports the presence of a novel hemotropic Mycoplasma species with 91.75\% sequence homology with Mycoplasma haemomuris. No differences were found in gene sequences generated from WNS and non-WNS animals.

Conclusions: Gene sequences generated from WNS and non-WNS animals suggest that little brown bats could serve as a natural reservoir for this potentially novel Mycoplasma species. Currently, there is minimal information about the prevalence, host-specificity, or the route of transmission of hemotropic Mycoplasma spp. among bats. Finally, the potential role of hemotropic Mycoplasma spp. as co-factors in the development of disease manifestations in bats, including WNS in Myotis lucifugus, remains to be elucidated.

Keywords: Hemotropic mycoplasma, Bat, Haemoplasma, Mycplasma, WNS

\section{Background}

Hemotropic mycoplasmas (hemoplasmas, formerly classified as Haemobartonella and Eperythrozoon spp.), are epicellular erythrocytic bacterial parasites lacking a cell wall, that can cause infectious anemia in some mammalian species [1-5]. Worldwide, hemotropic Mycoplasmas are emerging or re-emerging zoonotic pathogens that affect livestock [6-14], wildlife [15-19], companion animals [4,20-27], and humans [28-34]. These bacteria can cause serious and economically significant health problems in production animals. Infections with hemotropic

\footnotetext{
* Correspondence: rgmaggi@ncsu.edu

'College of Veterinary Medicine, North Carolina State University, 1060 William Moore Drive, Raleigh, NC 27607, USA

Full list of author information is available at the end of the article
}

Mycoplasmas can range from asymptomatic to illnesses characterized by overt life-threatening hemolytic anemia, subtle chronic anemia, ill-thrift, and infertility. In addition, these cell wall deficient bacteria may act as cofactors in the progression of retroviral, neoplastic, and immune-mediated diseases $[1,34,35]$. Unfortunately, little is known about hemotropic Mycoplasma spp. prevalence, host-specificity, or route of transmission in many wildlife species.

Historically, the diagnosis of hemotropic Mycoplasma infections relied upon cytological examination of stained blood smears. However, diagnostic sensitivity of blood smear examination is generally less than $20 \%$, and specificity is hampered by artifacts, such as stain precipitates and Howell-Jolly bodies [23,36,37]. The development of molecular assays, primarily targeting the $16 \mathrm{~S}$ rRNA gene of 
these microbes, has resulted in recognition of several novel animal hemotropic mycoplasmas [37-39], hence the host range has increased in recent years.

The objective of this study was to determine the molecular prevalence of hemotropic Mycoplasma species in a population of 68 little brown bats (Myotis lucifugus) from Northeastern and Eastern US. In addition, all bats were tested for Pseudogymnoascus (Geomyces) destructans, the causative agent of white nose syndrome (WNS) and cause of significant mortality events in bats, to determine if there was an association with Mycoplasma infection status.

\section{Methods}

\section{Sample collection}

A total of 68 dead little brown bats were sampled primarily during the mid-hibernation period from eastern and northeastern US (Pennsylvania, Ohio, Kentucky, West Virginia, Tennessee and North Carolina). Protocols for capturing, handling and sample collection followed the United States Fish and Wildlife Service Disinfection Protocol for Bat Studies. Dead bats collected by hand from roost substrates, were individually placed in plastic bags and stored at $-20^{\circ} \mathrm{C}$ until processing. Each bat was submitted to the Southeastern Cooperative Wildlife Disease Study at the College of Veterinary Medicine, University of Georgia, Athens, Georgia, where gross examination was carried out on carcasses. To avoid DNA crosscontamination, expendable supplies were used for each animal. Bat samples were tested for $P$. destructans by histological examination and molecular testing, either targeting the internal transcribed spacer (ITS) region of the rRNA gene complex $[40,41]$ or the intergenic spacer (IGS) region [42,43], as previously reported. Tissue samples (spleen) collected from each individual were placed in $70 \%$ ethanol and stored at $-80^{\circ} \mathrm{C}$ until DNA extraction and molecular analysis for evidence of hemotropic Mycoplasma infections were performed.

\section{Nucleic acid preparations}

Total DNA from $25 \mathrm{mg}$ of spleen tissue from each bat was extracted according to manufacturers instructions using a QIAamp DNA Mini Kit ${ }^{\mathrm{a}}$. After extraction, DNA concentration and quality was measured using absorbance ratio between $260 / 280 \mathrm{~nm}^{\mathrm{b}}$. DNA was stored at $-20^{\circ} \mathrm{C}$ until testing.

\section{PCR amplification}

Amplification of hemotropic Mycoplasma 16S rDNA was performed using two sets of oligonucleotides as previously described [17]: HemMycop16S-41 s: 5' GYA TGC MTA AYA CAT GCA AGT CGA RCG 3' and HemMyco16S938as: 5' CTC CAC CAC TTG TTC AGG TCC CCG TC 3' and HemMycop16S-322 s: 5' GCC CAT ATT CCT ACG
GGA AGC AGC AGT 3' and HemMycop16S- 1420as: 5' GTT TGA CGG GCG GTG TGT ACA AGA CC 3'. Sequences derived from amplicons obtained from each primer set (with an overlap of $600 \mathrm{bp}$ ) were aligned and edited using AlignX (Vector NTI suite 11.5.1). Amplification was performed in a $25-\mu \mathrm{l}$ final volume reaction, the $25 \mu \mathrm{L}$ reaction mix contained $12.5 \mu \mathrm{L}$ of Takara Ex Taq DNA Polymerase $^{\circledR}$ Premix (Fisher Scientific, Hampton, NH, USA), $0.2 \mu \mathrm{L}$ of $100 \mu \mathrm{M}$ of each forward and reverse primer, $7.3 \mu \mathrm{l}$ of molecular grade water and $5 \mu \mathrm{l}$ of template DNA. Five microliters of RNAse free water was used as a PCR negative control. Positive controls were prepared using $5 \mu \mathrm{l}$ of DNA from dog blood spiked with a 700 bp region of $M$. hematoparvum $16 \mathrm{~S}$ rRNA cloned in PGEM plasmid at a final concentration of 2 copies per microliter. Amplification was performed in an Eppendorf Mastercycler EPgradient $^{\circledR}$ (Hauppauge, NY, USA) as previously described [17]. PCR products were analyzed by $2 \%$ agarose gel electrophoresis and detected using ethidium bromide under ultraviolet light. Amplicon products were sequenced by Eton Bio, Inc (RTP, NC, USA) to establish species strain identification using chromatogram and alignment analysis (ContigExpress $^{\circledR}$ and AlignX software, Vector $\mathrm{NTI}^{\circledR}$ v10, Invitrogen, Carlsbad, CA, USA).

\section{Phylogenetic analysis}

Each 16S rRNA sequence was compared to 26 other hemotropic Mycoplasma sequences deposited in GenBank database in order to compare phylogenetic relatedness (evolutionary history) using the Neighbor-Joining method (MEGA4 ${ }^{\circledR}$ software). The tree is drawn to scale, with branch lengths in the same units as those of the evolutionary distances used to infer the phylogenetic tree. The evolutionary distances were computed using the Maximum Composite Likelihood method and are in the units of the number of base substitutions per site. MEGA4.

\section{Results \\ Molecular and histological examination of little brown bats}

From a total of 68 bats, 53 (78\%) had gross and histologic lesions consistent with WNS and were all PCR positive for $P$. destructans. The remaining 15 bats did not show any signs of clinical abnormalities or fungal infection.

\section{Hemotropic mycoplasma spp. DNA analysis}

A total of $32(47 \%)$ bats tested positive for hemotropic Mycoplasma spp. using primers targeting a region covering $700 \mathrm{bp}$ of the $16 \mathrm{~S}$ rRNA gene. All 32 sequences were identical. Interestingly, a similar prevalence was found for hemotropic Mycoplasma infection in bats with and without WNS (26/53 (49\%) and 6/15 (40\%) respectively). Mycoplasma amplification did not occur in 27 and 9 bats with and without evidence of WNS, respectively. There was no 
statistical difference (Fisher's exact, $\mathrm{p}=0.5725$ ) between the prevalence of hemotropic Mycoplasmas in WNS vs nonWNS affected bats.

A longer DNA sequence was obtained for 18 randomly selected PCR positive samples (four of which were from non-WNS animals), covering a 1,200 bp of the $16 \mathrm{~S}$ rRNA gene as previously described [19]. Again, all sequences were identical. Sequence analysis using 1103/1200 bp, identified the closest homology (91.9\%) to a hemotropic Mycoplasma detected in a human (Genbank GU562823), and 1101/1200 (91.8\%) with Mycoplasma haemomuris (AB758440), suggesting the presence a novel hemotropic Mycoplasma species in the sampled little brown bats (Figure 1). There were no differences in the Mycoplasma $16 \mathrm{~S}$ rDNA sequences derived from WNS-positive and WNS-negative animals. The 16SrRNA sequence of the hemotropic Mycoplasma species detected in bats was deposited in Genbank (accession number KF713538).

\section{Discussion}

Hemotropic Mycoplasma spp. appear to have co-evolved with many animal species. The development of molecular assays, primarily targeting the $16 \mathrm{~S}$ rRNA gene of these microbes, has resulted in the recent recognition of several novel animal and human hemoplasmas [15,17-19,44-47]. This study represents the first report of a novel, and as yet incompletely characterized hemotropic Mycoplasma species in little brown bats, with an overall prevalence of $47 \%$. There was no causative association with WNS, suggesting that this bat species acts as a natural reservoir for this uncharacterized Mycoplasma species. It is important to note that the results presented here may be biased either by the low number of bats assessed in either group or the lack of appropriate control bats obtained from non-WNS study sites. Therefore, conclusions on the role of hemotropic Mycoplasma as a potential co-factor in the development of WNS in bats cannot be derived from this study.

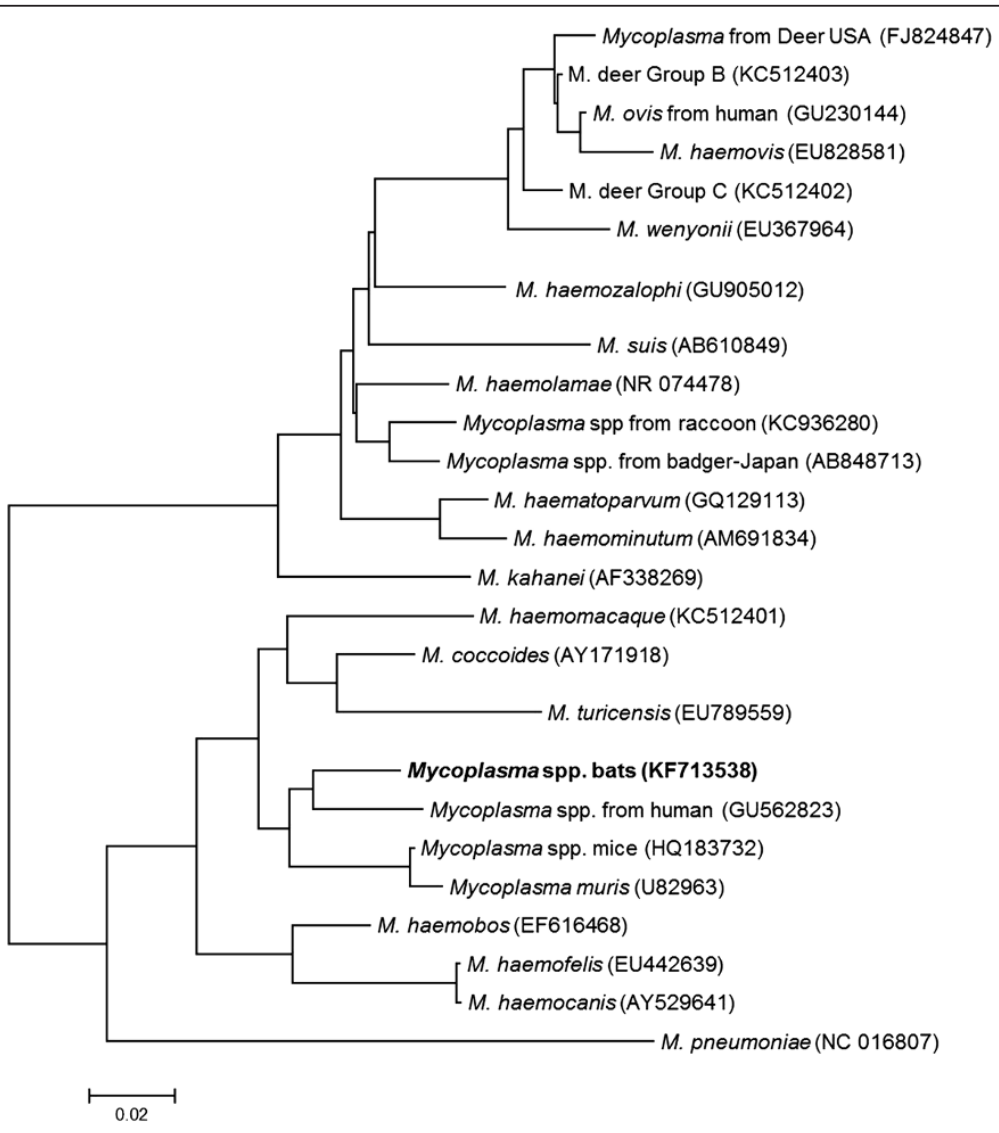

Figure 1 Neighborhood-joining analysis using 25 taxa of hemotropic Mycoplasma species (including Mycoplasma pneumonia) from the Genbank database and the 16S rRNA gene sequence obtained from the brown bats (Genbank accession KF713538) in this study. Candidatus status was omitted for simplicity. The evolutionary relationship was inferred using the Neighbor-Joining method. The optimal tree with the sum of branch length $=0.95954352$ is shown. The tree is drawn to scale, with branch lengths in the same units as those of the evolutionary distances used to infer the phylogenetic tree. The evolutionary distances were computed using the Maximum Composite Likelihood method and are in the units of the number of base substitutions per site. All positions containing gaps and missing data were eliminated from the dataset (Complete deletion option). Phylogenetic analyses were conducted in MEGA4. 


\section{Conclusion}

The relative high hemotropic Mycoplasmas DNA prevalence detected in WNS and non-WNS animals (49\% and $40 \%$ respectively) together with the sequence analysis generated from the 16SrRNA gene suggest that the little brown bats could serve as a natural reservoir for a novel hemotropic Mycoplasma species. Hemotropic Mycoplasma infection in mammals can cause a wide range of clinical conditions, from sub-clinical to life-threatening hemolytic anemia (particularly when immunosuppressed, stressed from poor nutrition, pregnancy, or lactation, or when concurrently infected with other more virulent pathogens, or more than one Mycoplasma species) $[1,27,48]$. Currently, there is no information about the prevalence, host-specificity, or the route of transmission of hemotropic Mycoplasma spp. in bats. The potential role of hemotropic Mycoplasma as a cause of disease manifestations, and specifically WNS in Myotis lucifugus remains to be elucidated.

\section{Endnotes}

${ }^{a}$ QIAGEN Inc., Valencia, CA.

${ }^{\mathrm{b}}$ Nanodrop, Thermo Scientific, USA.

\section{Abbreviations}

WNS: White nose syndrome; RTP: Research Triangle Park.

\section{Competing interests}

The authors declare that they have no competing interests.

\section{Authors' contributions}

PEM, RGM, and LAL performed the PCR testing of the patient samples, performed DNA sequencing and alignments. MKK and LAL assisted in sample acquisition and testing. EBB, MY, and RGM coordinated various aspects of the investigation. EBB, PEM, and RGM helped to draft the final manuscript. All authors read and approved the manuscript.

\section{Acknowledgement}

We would like to thank Tonya Lee for editorial assistance with this manuscript, and Bayer HealthCare-Animal Health Division, for the support on this publication. This project was funded in part by the state of North Carolina.

\section{Author details}

'College of Veterinary Medicine, North Carolina State University, 1060 William Moore Drive, Raleigh, NC 27607, USA. ²Department of Population Health, Southeastern Cooperative Wildlife Disease Study, College of Veterinary Medicine, University of Georgia, Athens, GA 30602, USA. ${ }^{3}$ Department of Pathology, Microbiology, and Immunology, University of California, Davis, CA 95616, USA. ${ }^{4}$ D.B. Warnell School of Forestry and Natural Resources, University of Georgia, Athens, GA 30602, USA.

Received: 13 December 2013 Accepted: 18 March 2014 Published: 24 March 2014

\section{References}

1. Messick JB: Hemotrophic mycoplasmas (hemoplasmas): a review and new insights into pathogenic potential. Vet Clin Pathol 2004, 33(1):2-13.

2. Biondo AW, Dos Santos AP, Guimaraes AM, Vieira RF, Vidotto O, Macieira Dde B, Almosny NR, Molento MB, Timenetsky J, de Morais HA, González FH, Messick JB: A review of the occurrence of hemoplasmas (hemotrophic mycoplasmas) in Brazil. Rev Bras Parasito/ Vet 2009, 18(3):1-7.

3. Hoelzle LE: Haemotrophic mycoplasmas: recent advances in Mycoplasma suis. Vet Microbiol 2008, 130(3-4):215-226.

4. Sykes JE: Feline hemotropic mycoplasmas. J Vet Emerg Crit Care (San Antonio) 2010, 20(1):62-69.
5. Shang DQ, Li LY, Lu ZG: [An epidemiological investigation of eperythrozoon infection in human and animals (III)]. Zhonghua Liu Xing Bing Xue Za Zhi 1997, 18(3):150-152.

6. Fujihara Y, Sasaoka F, Suzuki J, Watanabe Y, Fujihara M, Ooshita K, Ano H, Harasawa R: Prevalence of hemoplasma infection among cattle in the western part of Japan. J Vet Med Sci 2011, 73(12):1653-1655.

7. Hoelzle K, Hofmann-Lehmann R, Hoelzle LE: 'Candidatus Mycoplasma haemobos', a new bovine haemotrophic Mycoplasma species? Vet Microbiol 2010, 144(3-4):525-526.

8. Nicholas RA, Ayling RD: Mycoplasma bovis: disease, diagnosis, and control. Res Vet Sci 2003, 74(2):105-112.

9. Aguirre DH, Thompson C, Neumann RD, Salatin AO, Gaido AB, de Echaide ST: Clinical mycoplasmosis outbreak due to Mycoplasma ovis in sheep from Shalta, Argentina. Clinical, microbiological and molecular diagnosis. Rev Argent de Microbiol 2009, 41(4):212-214.

10. Neimark H, Hoff B, Ganter M: Mycoplasma ovis comb. nov. (formerly Eperythrozoon ovis), an epierythrocytic agent of haemolytic anaemia in sheep and goats. Int J Syst Evol Microbiol 2004, 54(Pt 2):365-371.

11. Suzuki J, Sasaoka F, Fujihara M, Watanabe Y, Tasaki T, Oda S, Kobayashi S, Sato R, Nagai K, Harasawa R: Molecular identification of 'Candidatus Mycoplasma haemovis' in sheep with hemolytic anemia. J Vet Med SC 2011, 73(8):1113-1115.

12. Tagawa M, Takeuchi T, Fujisawa T, Konno Y, Yamamoto S, Matsumoto K, Yokoyama N, Inokuma H: A clinical case of severe anemia in a sheep coinfected with Mycoplasma ovis and 'Candidatus Mycoplasma haemovis' in Hokkaido, Japan. J Vet Med Sci 2012, 74(1):99-102.

13. Dieckmann SM, Winkler M, Groebel K, Dieckmann MP, Hofmann-Lehmann R, Hoelzle K, Wittenbrink MM, Hoelzle LE: Haemotrophic Mycoplasma infection in horses. Vet Microbiol 2010, 145(3-4):351-353.

14. Groebel K, Hoelzle K, Wittenbrink MM, Ziegler U, Hoelzle LE: Mycoplasma suis invades porcine erythrocytes. Infect Immun 2009, 77(2):576-584.

15. Boes KM, Goncarovs KO, Thompson CA, Halik LA, Santos AP, Guimaraes AM, Feutz MM, Holman PJ, Vemulapalli R, Messick JB: Identification of a Mycoplasma ovis-like organism in a herd of farmed white-tailed deer (Odocoileus virginianus) in rural Indiana. Vet Clin Pathol 2012, 41(1):77-83.

16. Grazziotin AL, Santos AP, Guimaraes AM, Mohamed A, Cubas ZS, de Oliveira MJ, dos Santos LC, de Moraes W, Vieira RF, Donatti L, de Barros Filho IR, Biondo AW, Messick JB: Mycoplasma ovis in captive cervids: prevalence, molecular characterization and phylogeny. Vet Microbiol 2011, 152(3-4):415-419.

17. Maggi RG, Chitwood MC, Kennedy-Stoskopf S, DePerno CS: Novel hemotropic Mycoplasma species in white-tailed deer (Odocoileus virginianus). Comp Immunol Microbiol Infect Dis 2013, 36(6):607-611.

18. Willi B, Filoni C, Catao-Dias JL, Cattori V, Meli ML, Vargas A, Martinez F, Roelke ME, Ryser-Degiorgis MP, Leutenegger CM, Lutz H, HofmannLehmann R: Worldwide occurrence of feline hemoplasma infections in wild felid species. J Clin Microbiol 2007, 45(4):1159-1166.

19. Maggi RG, Mascarelli PE, Balakrishnan N, Rohde CM, Kelly CM, Ramaiah L, Leach MW, Breitschwerdt EB: "Candidatus Mycoplasma haemomacaque" and Bartonella quintana bacteremia in cynomolgus monkeys. J Clin Microbiol 2013, 51(5):1408-1411.

20. Messick JB: New perspectives about Hemotrophic mycoplasma (formerly, Haemobartonella and Eperythrozoon species) infections in dogs and cats. Vet Clin North Am Small Anim Pract 2003, 33(6):1453-1465.

21. Novacco M, Boretti FS, Wolf-Jackel GA, Riond B, Meli ML, Willi B, Lutz H, Hofmann-Lehmann R: Chronic "Candidatus Mycoplasma turicensis" infection. Vet Res 2011, 42(1):59.

22. Roura X, Peters IR, Altet L, Tabar MD, Barker EN, Planellas M, Helps CR, Francino O, Shaw SE, Tasker S: Prevalence of hemotropic mycoplasmas in healthy and unhealthy cats and dogs in Spain. J Vet Diagn Invest 2010 22(2):270-274

23. Tasker S, Lappin MR: Haemobartonella felis: recent developments in diagnosis and treatment. J Feline Med Surg 2002, 4(1):3-11

24. Sykes JE, Terry JC, Lindsay LL, Owens SD: Prevalences of various hemoplasma species among cats in the United States with possible hemoplasmosis. J Am Vet Med Assoc 2008, 232(3):372-379.

25. Compton SM, Maggi RG, Breitschwerdt EB: Candidatus Mycoplasma haematoparvum and Mycoplasma haemocanis infections in dogs from the United States. Comp Immunol Microbiol Infect Dis 2012, 35(6):557-562.

26. Novacco M, Meli ML, Gentilini F, Marsilio F, Ceci C, Pennisi MG, Lombardo G, Lloret A, Santos L, Carrapico T, Willi B, Wolf G, Lutz H, Hofmann-Lehmann R: 
Prevalence and geographical distribution of canine hemotropic mycoplasma infections in Mediterranean countries and analysis of risk factors for infection. Vet Microbio/ 2010, 142(3-4):276-284.

27. Willi B, Novacco M, Meli M, Wolf-Jackel G, Boretti F, Wengi N, Lutz H, Hofmann-Lehmann R: Haemotropic mycoplasmas of cats and dogs: transmission, diagnosis, prevalence and importance in Europe. Schweiz Arch Tierheilkd 2010, 152(5):237-244.

28. dos Santos AP, dos Santos RP, Biondo AW, Dora JM, Goldani LZ, de Oliveira ST, de Sa Guimaraes AM, Timenetsky J, de Morais HA, Gonzalez FH, Messick JB: Hemoplasma infection in HIV-positive patient, Brazil. Emerg Infect Dis 2008, 14(12):1922-1924.

29. Hu Z, Yin J, Shen K, Kang W, Chen Q: Outbreaks of hemotrophic mycoplasma infections in China. Emerg Infect Dis 2009, 15(7):1139-1140.

30. Steer JA, Tasker S, Barker EN, Jensen J, Mitchell J, Stocki T, Chalker VJ, Hamon M: A novel hemotropic Mycoplasma (hemoplasma) in a patient with hemolytic anemia and pyrexia. Clin Infect Dis 2011, 53(11):e147-e151.

31. Bandi KM, Saikumar C: Sarcoptic mange: a zoonotic ectoparasitic skin disease. J Clin Diagn Res 2013, 7(1):156-157.

32. Hobi S, Linek M, Marignac G, Olivry T, Beco L, Nett C, Fontaine J, Roosje P, Bergvall K, Belova S, Koebrich S, Pin D, Kovalik M, Meury S, Wilhelm S, Favrot C: Clinical characteristics and causes of pruritus in cats: a multicentre study on feline hypersensitivity-associated dermatoses. Vet Dermatol 2011, 22(5):406-413.

33. Huang DS, Guan P, Wu W, Shen TF, Liu HL, Cao S, Zhou H: Infection rate of Eperythrozoon spp. in Chinese population: a systematic review and meta-analysis since the first Chinese case reported in 1991. BMC Infect Dis 2012, 12:171

34. Maggi RG, Compton SM, Trull CL, Mascarelli PE, Mozayeni BR, Breitschwerdt EB: Infection with hemotropic Mycoplasma species in patients with or without extensive arthropod or animal contact. J Clin Microbiol 2013, 51(10):3237-3241.

35. Eremeeva ME, Karpathy SE, Levin ML, Caballero CM, Bermudez S, Dasch GA Motta JA: Spotted fever rickettsiae, Ehrlichia and Anaplasma, in ticks from peridomestic environments in Panama. Clin Microbiol Infect 2009, 15(Suppl 2):12-14

36. Tasker S, Helps CR, Day MJ, Harbour DA, Shaw SE, Harrus S, Baneth G, Lobetti RG, Malik R, Beaufils JP, Belford CR, Gruffydd-Jones TJ: Phylogenetic analysis of hemoplasma species: an international study. J Clin Microbiol 2003, 41(8):3877-3880.

37. Willi B, Boretti FS, Tasker S, Meli ML, Wengi N, Reusch CE, Lutz H, HofmannLehmann R: From Haemobartonella to hemoplasma: molecular methods provide new insights. Vet Microbio/ 2007, 125(3-4):197-209.

38. Birkenheuer AJ, Breitschwerdt EB, Alleman AR, Pitulle C: Differentiation of Haemobartonella canis and Mycoplasma haemofelis on the basis of comparative analysis of gene sequences. Am J Vet Res 2002, 63(10):1385-1388.

39. Sykes JE, Lindsay LL, Maggi RG, Breitschwerdt EB: Human coinfection with Bartonella henselae and two hemotropic mycoplasma variants resembling Mycoplasma ovis. J Clin Microbiol 2010, 48(10):3782-3785.

40. Lindner DL, Gargas A, Lorch JM, Banik MT, Glaeser J, Kunz TH, Blehert DS: DNA-based detection of the fungal pathogen Geomyces destructans in soils from bat hibernacula. Mycologia 2011, 103(2):241-246.

41. Lorch JM, Gargas A, Meteyer CU, Berlowski-Zier BM, Green DE, Shearn-Bochsler V, Thomas NJ, Blehert DS: Rapid polymerase chain reaction diagnosis of white-nose syndrome in bats. J Vet Diagn Invest 2010, 22(2):224-230.

42. Lorch JM, Lindner DL, Gargas A, Muller LK, Minnis AM, Blehert DS: A culturebased survey of fungi in soil from bat hibernacula in the eastern United States and its implications for detection of Geomyces destructans, the causal agent of bat white-nose syndrome. Mycologia 2013, 105(2):237-252.

43. Muller LK, Lorch JM, Lindner DL, O'Connor M, Gargas A, Blehert DS: Bat white-nose syndrome: a real-time TaqMan polymerase chain reaction test targeting the intergenic spacer region of Geomyces destructans. Mycologia 2013, 105(2):253-259

44. Sykes JE, Ball LM, Bailiff NL, Fry MM: 'Candidatus Mycoplasma haematoparvum', a novel small haemotropic mycoplasma from a dog. Int J Syst Evol Microbiol 2005, 55(Pt 1):27-30.

45. Barker EN, Tasker S, Day MJ, Warman SM, Woolley K, Birtles R, Georges KC, Ezeokoli CD, Newaj-Fyzul A, Campbell MD, Sparagano OA, Cleaveland S, Helps CR: Development and use of real-time PCR to detect and quantify Mycoplasma haemocanis and "Candidatus Mycoplasma haematoparvum" in dogs. Vet Microbiol 2010, 140(1-2):167-170.

46. Hornok S, Meli ML, Gonczi E, Ignits E, Willi B, Lutz H, Hofmann-Lehmann R: First molecular identification of 'Candidatus mycoplasma haemominutum' from a cat with fatal haemolytic anaemia in Hungary. Acta Vet Hung 2008, 56(4):441-450

47. Vieira RF, Molento MB, Guimaraes AM, Santos AP, Bonat M, Javorouski ML, Popp L, Santos LC, Moraes W, Cubas ZS, Vieira TS, Vidotto O, Filho IR, Biondo AW, Messick JB: Use of a Mycoplasma suis-PCR protocol for screening a population of captive peccaries (Tayassu tajacu and Tayassu pecari). Rev Bras Parasitol Vet 2011, 20(1):75-77.

48. Willi B, Boretti FS, Baumgartner C, Tasker S, Wenger B, Cattori V, Meli ML, Reusch CE, Lutz H, Hofmann-Lehmann R: Prevalence, risk factor analysis, and follow-up of infections caused by three feline hemoplasma species in cats in Switzerland. J Clin Microbiol 2006, 44(3):961-969.

doi:10.1186/1756-3305-7-117

Cite this article as: Mascarelli et al:: Hemotropic mycoplasmas in little brown bats (Myotis lucifugus). Parasites \& Vectors 2014 7:117.

\section{Submit your next manuscript to BioMed Central and take full advantage of:}

- Convenient online submission

- Thorough peer review

- No space constraints or color figure charges

- Immediate publication on acceptance

- Inclusion in PubMed, CAS, Scopus and Google Scholar

- Research which is freely available for redistribution

Submit your manuscript at www.biomedcentral.com/submit
C Biomed Central 